\title{
RESPIRATION IN CHONDRACANTHUS ZEI DE LA ROCHE (COPEPODA)
}

\author{
By S. KRISHNASWAMY ${ }^{1}$
}

Department of Zoology, University, Southampton

(Text figs. I-3)

In spite of the keen interest evinced in the taxonomy of the parasitic copepods, there is little information on their metabolic rate, though the respiration of free-living forms has been studied by such workers as Marshall \& Orr (1955, I957), Clarke \& Bonnett (1939), Zeuthen (1947), Raymont \& Gauld (I95I), Gauld \& Raymont (I953) and Conover (1956). Since the rate of oxygen consumption is a reflexion of the metabolic rate of an animal, it was felt that a study of the rate of oxygen consumption of a copepod parasite would be of interest. Chondracanthus zei De la Roche, I8II, is easily available and large.

C. $z e i$ is found on the gills and gill-arches of Zeus faber and is 'almost always present' (Oakley, 1930). Usually two to three parasites are found in each fish. It is a relatively large parasite, about $\mathrm{I} \cdot 3 \mathrm{~cm}$, and weighing up to $200 \mathrm{mg}$. It shows little movement in life except for occasional twitches, and is so deeply embedded in the tissue as to form a deep wound.

\section{MATERIAL AND METHODS}

The work was carried out at the Marine Biological Laboratory at Plymouth. The respiratory rate was followed in a Warburg manometer. Two to four animals, depending on their size, were used in each flask with $3 \mathrm{ml}$. of sea water; the $\mathrm{CO}_{2}$ was absorbed by a roll of starch-free filter-paper dipping into $0.2 \mathrm{ml}$. of $20 \% \mathrm{KOH}$ contained in the central wall of the flask. The manometers were shaken at sixty oscillations per minute. It was found that shaking did not damage the animal nor apparently in any way depress the respiratory rate. Pressures were corrected every $15 \mathrm{~min}$ and each experiment lasted for $3 \mathrm{~h}$ approximately. In all thirty-seven experiments were performed, but on occasions the same animals were used in more than one experiment owing to the difficulty in procuring enough material. All the experiments were carried out at $20^{\circ} \mathrm{C}$. After each experiment, the animals were transferred on to filter-paper and weighed, and were then dried to constant weight in an oven at $100^{\circ} \mathrm{C}$.

\section{RESULTS AND DISCUSSION}

The overall respiration rate varied from ig to $30 \mu 1$. per copepod per hour. The same results expressed as oxygen consumed per mg dry weight per hour varied from $0 \cdot 19$ to $I \cdot 8 \mu \mathrm{l}$. depending on the size of the animal. There is a wide scatter (Fig. I), especially in the smaller animals (50-60 mg range), which may

\footnotetext{
1 Colombo Plan Research Fellow.
} 
partly be due to individual differences in respiratory rate. Nevertheless, the rate of oxygen consumption evidently shows a fall with increase in weight as has been shown in many poikilotherms by Zeuthen (1947). It is interesting to find a similar relationship for parasitic forms also. Von Brand (I953) mentions a similar trend in many endoparasitic animals, but unfortunately no information is available for comparison on external parasites.

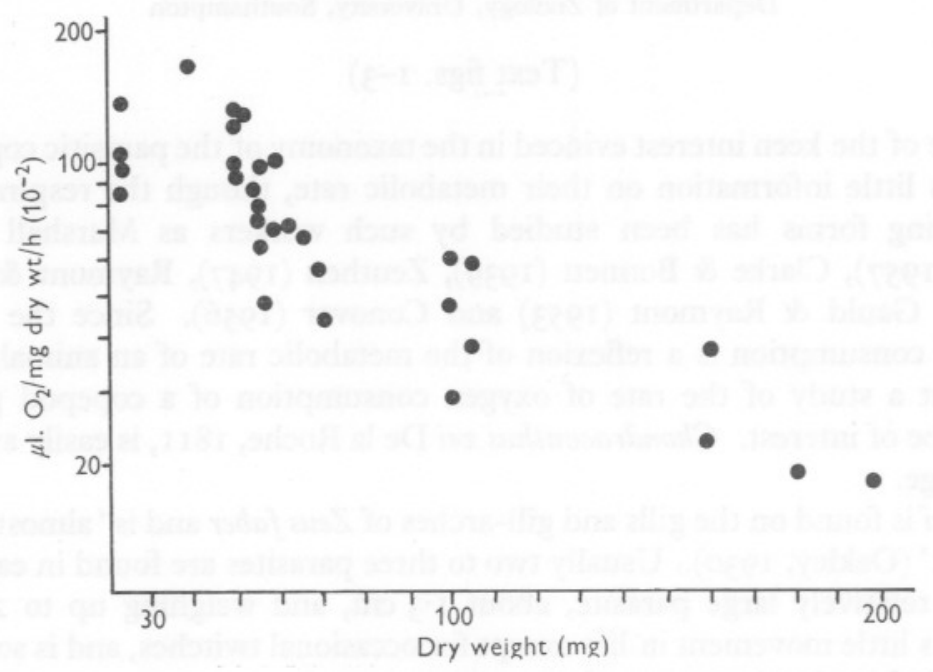

Fig. I. Variations in the rate of oxygen consumption with body weight.

Marshall \& Orr (1955, p. II5) observed that immediately after capture Calanus has a considerably higher respiration rate than some hours later, the fall being marked in the first few hours and not noticeable after about one day. Raymont \& Gauld (195I) also found a similar fall in respiratory rate with time. During the present study the same trend was observed: the respiratory rate remained steady over a period of $3 \mathrm{~h}$, but thereafter decreased. The results of a few experiments run continuously for $8 \mathrm{~h}$ clearly show that at the end the respiratory rate had fallen to a sixth of the initial rate (Fig. 2). This fall in respiratory rate probably explains much of the wide scatter in Fig. I, since the same set of animals was used in more than one experiment. Experiments using the same animals on the second and third days also revealed a similar fall in respiratory rate (Fig. 3). However, on transfer to fresh sea water after each experiment, there appeared to be recovery in the rate, as evident from the gradual slope of Fig. 3. It is therefore probable that the decline in respiration was partly dependent on the oxygen tension in these long-term experiments.

The rate of oxygen uptake in Chondracanthus appears to be low as compared with a free-living copepod such as Calanus finmarchicus. A Calanus 
weighing $0.30 \mathrm{mg}$ respires $0.75 \mu \mathrm{l} . \mathrm{O}_{2}$, a relatively very large parasite weighing $200 \mathrm{mg}$ requires only $0.19 \mu 1 . / \mathrm{mg}$ dry $\mathrm{wt} / \mathrm{h}$. This difference is presumably correlated with the parasite being less active.

A calculation shows that a Chondracanthus weighing $200 \mathrm{mg}$ will require $3.85 \%$ of its own body weight of food for its maintenance according to the $\mathrm{O}_{2}$ uptake. In his review of Chondracanthidae Oakley (1930) states that these parasites probably live on a mixed diet of flesh and blood, and therefore the damage to the host must be considerable.

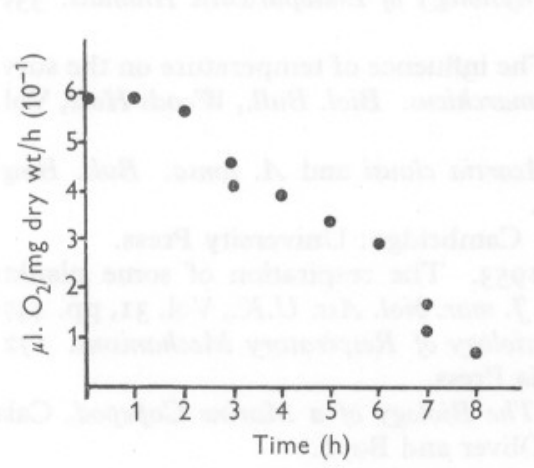

Fig. 2

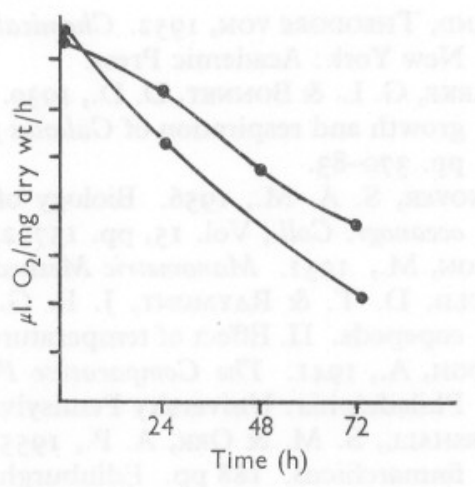

Fig. 3

Fig. 2. Fall in respiratory rate with time, in experiments run for $8 \mathrm{~h}$ continuously.

Fig. 3. Fall in respiratory rate with time, in experiments done on successive days.

In many animals a relationship has been established between surface area and respiration (Zeuthen, I947, I953). In a large parasite, like Chondracanthus, which lacks an efficient circulatory system, most of the oxygen required will have to be obtained by diffusion. Krogh (I94I) pointed out that mere diffusion through the body surface may be insufficient to supply all the oxygen required in animals larger than $2 \mathrm{~mm}$. It is therefore possible that the number of projections from the body surface helps to increase the surface area. Furthermore, Chondracanthus being located on the gill-arches is thereby exposed to a constant flow of fully oxygenated water so that the rate of diffusion of oxygen is maximal.

The author is indebted to Prof. J. E. G. Raymont of Southampton University for suggesting this problem and for helpful suggestions and criticisms. He also thanks the Director and Staff of the Marine Biological Laboratory, Plymouth, for the unfailing courtesy shown to him and for help and facilities. $\mathrm{He}$ is grateful to Dr E. D. S. Corner and Miss J. Lance for discussions and suggestions. 


\section{SUMMARY}

The rate of oxygen consumption in Chondracanthus zei varied from 0.19 to $\mathrm{I} \cdot 8 \mu \mathrm{l}$./mg dry $\mathrm{wt} / \mathrm{h}$ depending on the body weight. There is a fall in respiratory rate with time. The metabolic rate as reflected by $\mathrm{O}_{2}$ requirements shows that the animal may consume about $3.85 \%$ of its own body weight of food per day.

\section{REFERENCES}

Brand, Theodore von, 1952. Chemical Physiology of Endoparasitic Animals. 339 pp. New York: Academic Press.

Clarke, G. L. \& Bonnet, D. D., 1939. The influence of temperature on the survival, growth and respiration of Calanus finmarchicus. Biol. Bull., Woods Hole, Vol. 76, pp. 370-83.

Conover, S. A. M., 1956. Biology of Acartia clausi and A. tonsa. Bull. Bingham oceanogr. Coll., Vol. 15, pp. 157-233.

Dixon, M., I95I. Manometric Methods. Cambridge: University Press.

Gauld, D. T. \& RAYMonT, J. E. G., 1953. The respiration of some planktonic copepods. II. Effect of temperature. F. mar. biol. Ass. U.K., Vol. 31, pp. 447-60.

Krogh, A., I94I. The Comparative Physiology of Respiratory Mechanisms. I72 pp. Philadelphia: University Pennsylvania Press.

Marshall, S. M. \& OrR, A. P., I955. The Biology of a Marine Copepod, Calanus finmarchicus. $188 \mathrm{pp}$. Edinburgh: Oliver and Boyd.

— 1957. A preliminary note on seasonal changes in respiration in copepods. Année. Biol., Vol. 33, pp. 22I-6.

- 1958. On the biology of Calanus finmarchicus. X. Seasonal changes in oxygen consumption. F. mar. biol. Ass. U.K., Vol. 37, pp. 459-72.

OAKLEY, C. L., I930. The Chondracanthidae (Crustacea: Copepoda) with a description of five new genera and one new species. Parasitology, Vol. 22, pp. 182-20I.

RAYMONT, J. E. G. \& GAULD, D. T., I95I. Respiration of some planktonic copepods. F. mar. biol. Ass. U.K., Vol. 29, pp. 681-93.

Scott, T. E. A., I913. The Parasitic Copepoda, Vol. I, 252 pp. London: Ray Society.

ZEUTHEN, E., I947. Body size and metabolic rate in the animal kingdom. C.R. Lab. Carlsberg, Ser. Chim, T. 26, pp. I-165.

- 1953. Oxygen uptake as related to body size in organisms. Quart. Rev. Biol., Vol. 28, pp. I-I2. 